\title{
The status of traditional healing in the Limpopo province of South Africa
}

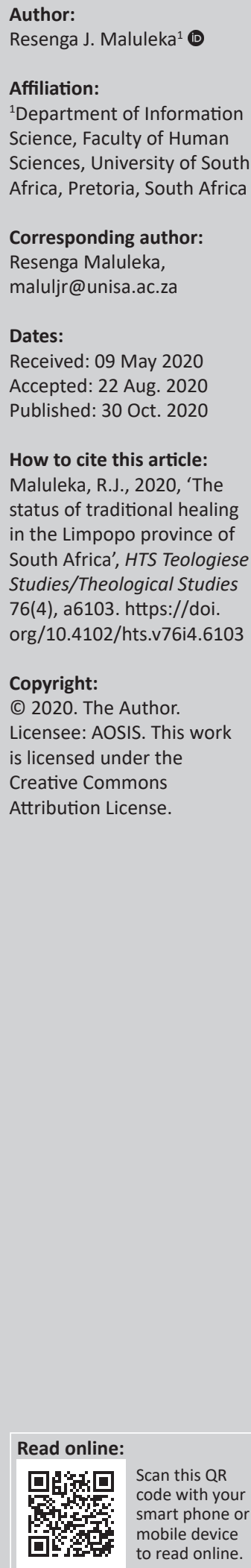

Traditional healing and the use of traditional medicines were historically banned by the South African apartheid government. The dawn of democracy saw a change in the laws, which gave freedom to the traditional African practices. Nevertheless, many South Africans are still divided between Western- and traditional African philosophies. This qualitative study, therefore, employed the hermeneutic phenomenological method to investigate the status of traditional healing in the Limpopo province of South Africa. Data collection was done through interviews, and data were analysed thematically. The results suggest that the work done by traditional healers remains marginalised and undermined despite them contributing to the country's healthcare system. Traditional healers remain unregulated and often left to work on their own under difficult conditions. It is recommended that government play an active role in ensuring that healers are formally incorporated into the country's healthcare system, which will benefit both the healers and the communities they serve.

Contribution: The study investigates the current status of traditional healing in South Africa and highlights that despite having laws that support traditional healing in the country, the practice remains marginalised and healers are working on their own and not within the country's healthcare system as it is supposed to be. The study is linked to the scope of the journal because it investigates a topic that borders on oral history and indigenous religious practices of South Africans.

Keywords: traditional healing; traditional healers; healthcare system; indigenous knowledge; Traditional Health Council; traditional healers associations; Limpopo province; South Africa.

\section{Introduction and background of the study}

William Feather (1889-1981), an American author, once wrote that 'every social injustice is not only cruel, but it is an economic waste'. Traditional healing was subjected to social injustice in South Africa over the years, more so during the apartheid era. The fall of the then apartheid government in South Africa brought with it many changes and had a direct influence on many other things, including traditional African practices. Apartheid was a system of institutionalised racial segregation and discrimination in South Africa, which forced different racial groups to live separately and unequally.

The impact of changes brought by the fall of the apartheid government is evident in many communities, which currently subscribe to different views about indigenous healing and many other African beliefs because of what they have been exposed to and forced to do by the apartheid government. To that effect, Mokgobi (2014:24) highlights that many South Africans are still divided between Western and traditional African philosophies. These divisions are mainly on issues like gender, religion, medicine, ceremonies and other practices that affect our daily lives. This makes South Africa, which is often referred to as a 'rainbow nation', unique, as it consists of diverse cultures and beliefs when compared to other parts of the world.

During the apartheid era, the use of traditional medicine in South Africa was outlawed. According to the Union Gazette Extraordinary (1957:3), the South African apartheid government passed into law the Suppression of Witchcraft Act in 1957, a piece of colonial legislation, which declared divination including traditional healing to be illegal, thereby theoretically making the work of traditional healers impossible. Traditional healing was associated with witchcraft and that stigma continues to shadow traditional healing even today.

Note: Special Collection entitled Social Memory Studies, sub-edited by Christina Landman (UNISA) and Sekgothe Mokgoatšana (UL). 
Despite all the challenges, African traditional beliefs stood the test of time and were always widely practised in secret, mainly because of apartheid laws and the missionaries from the Congregational, Methodist, Anglican, Lutheran and Catholic churches. The missionaries were aggressively opposed to traditional African practices because, according to them, these were barbaric and based on superstitions (Denis 2006:312). Such churches openly discouraged their members from consulting traditional healers because it was indicated that traditional healers worshipped the ancestors and not God, which was seen as a sin in the Christian orthodoxy (Mokgobi 2014:25). Those born during and after apartheid were affected the worst because they were born in a time when their cultures and practices were eroded.

The negative stories related to traditional healing published by the media have also played a negative role in how the current generation views this practice. There has been an array of media reports of traditional healers claiming to have a cure for acquired immunodeficiency syndrome (AIDS), or submitting their patients to dangerous or ineffective treatments (Richter 2003:12). There are also unproven stories in the news about suspected killings that are linked to traditional healing and traditional healers where it is believed that people are killed for their body parts to be used for healing purposes.

Some churches, like the Zionist church, have similarities with some forms of indigenous religions, as well as some Christian churches, which have some level of tolerance for the traditional African religions (Denis 2006:313). Such churches allow people to continue with their traditional ways of living whilst continuing to be members of their congregations. Denis (2006:313) indicates that Christianity and traditional African religion have been transformed into a polarity with an infinite variety of intermediary positions and multiple interactions between the two poles. This means that Africans may attend a church service whilst still practising their own rituals and visiting traditional healers.

The situation has changed drastically over the last few decades. Sodi et al. (2011:101) indicate that the work of traditional healers is receiving attention, particularly the role that traditional healers can and continue to play in preventative, promotive, curative, rehabilitative and psychosocial care of patients. The South African postapartheid government recognises a person who engages in indigenous medical plants as an indigenous healer (Sodi et al. 2011:101). The South African government has also passed into law the Traditional Health Practitioners (THP) Act, No. 22 of 2007, which regulates the activities of indigenous healers. The Act states that 'traditional healing' means the performance of a function, activity, process or service based on a traditional philosophy that includes the utilisation of traditional medicine (Government Gazette 2008:s. 21(2) (b)). This meant that traditional healers were free to practise and were protected by law.
According to the THP Act, any person who wishes to register as a traditional health practitioner or a student must apply to the registrar of the Interim Traditional Health Practitioners Council of South Africa (Government Gazette 2008). If the registrar is satisfied that the information and documentation submitted in support of an application for registration meet the requirements of this Act, and upon receipt of the prescribed registration fee, the registrar may issue a registration certificate, authorising the applicant to practise as a traditional health practitioner in the Republic of South Africa (THP Act of 2007, s. 21[2] [b]).

Mokgobi (2014:31) is of the opinion that the duties of healers go beyond the use of herbs for curing illnesses. In addition to working with herbs and healing the sick, traditional healers are custodians of the traditional African religion and customs, educators about culture, counsellors, social workers and psychologists (Mokgobi 2014:31). Mathibela et al. (2015:234), however, caution that the South African government's healthcare system has had a negative impact on the practice of traditional healing, as patients consult government healthcare centres before turning to traditional healers. During such visits, some doctors in hospitals discourage patients from consulting traditional healers for health reasons. According to Summerton (2006:17), Western health practitioners' critical view of traditional medicine is influenced by the lack of knowledge about traditional theories of disease and health by some doctors, and this causes mistrust between the two sides.

\section{Contextual setting}

According to Mokgobi (2014:29), in South Africa, traditional healers are called differently in different parts of the country. In the Limpopo province, the Bapedi tribals call their healers 'Dingaka', the Vendas call their healers 'VhoMaine', whilst the Tsongas call their healers 'Mungome'. These types of healers are mainly diviners who use bones and the spirits of the ancestors to diagnose and prescribe medication for different physiological, psychiatric and spiritual conditions (Mokgobi 2014:29). This study will pay particular attention to the traditional healers in the Limpopo province. These healers will mainly speak Sepedi, Tsonga and Venda, as these are the three main languages spoken in Limpopo.

This study was conducted in five regions of the Limpopo province, namely, Waterberg, Capricorn, Vhembe, Mopani and Sekhukhune (Maluleka \& Ngoepe 2018:5). Limpopo is the northern-most province in South Africa, lying within the great curve of the Limpopo River from which the province has derived its name. The province borders the countries of Botswana to the west, Zimbabwe to the north and Mozambique to the east (Limpopo Provincial Government 2014:1).

\section{Problem statement}

Historically, traditional healing was outlawed in South Africa. During the apartheid era, the Suppression of Witchcraft 
Act of 1957 (Union Gazette Extraordinary 1957) barred the use of traditional medicine in South Africa. This piece of legislation forced traditional healers to practise their craft secretly for fear of arrests. Traditional healing was associated with witchcraft and that stigma continues to shadow traditional healing even today. This is evident in the array of media reports of traditional healers linked to murders and submitting their patients to dangerous or ineffective treatments (Richter 2003:12). The fall of the then apartheid government in South Africa brought with it many changes and also had a direct influence on a number of societal issues, including traditional African practices. Many communities subscribe to different religious beliefs because of what they were exposed to, during the historical past. Many South Africans are still divided between Western and traditional African philosophies. Since the dawn of democracy, the South African government has passed into law the THP Act which is expected to regulate the activities of traditional healers in the country. However, despite having a piece of legislation that encourages and supports traditional healing, traditional healers remain marginalised, mistrusted and misunderstood (Summerton 2006:21). Therefore, this study aims to look at the current status of traditional healing in the Limpopo province of South Africa.

\section{Objectives of the study}

The overall objective of the study was to investigate the status of traditional healing in the Limpopo province of South Africa.

\section{Brief literature review}

Various studies (Ashforth 2005; Denis 2006; Mathibela et al. 2015; Mokgobi 2014; Richter 2003; Sodi et al. 2011; Summerton 2006) have investigated traditional healing in South Africa over the years. Sodi et al. (2011) observed that the studies in this area mainly focused on how individuals become healers, as well as on how the healing process had been performed, whilst other studies were more focused on different medicinal plants and their benefits. Internationally, Maher (1999) conducted a literature review on traditional aboriginal health beliefs and medical practices and found that the traditional health beliefs of aboriginal people are interconnected with many aspects of aboriginal life, such as the land, kinship obligations and religion. Furthermore, the study revealed that traditional aboriginal medical treatment includes bush medicines, the traditional healer singing/chanting and the utilisation of external remedies. This is similar to what used to be in South Africa before colonisation and urbanisation. Different groups under the same king occupying a particular land would share the same cultural beliefs.

Mokgobi (2014) also conducted a study entitled 'Understanding traditional African healing', which discusses the types of traditional healers, training of traditional healers and the role of traditional healers in different communities. As explained by Sodi et al. (2011), this is one of those studies that mainly focused on the healing process, whilst the current study investigates the status of traditional healing. The study by Mokgobi (2014), however, goes a step further to suggest that healers are also custodians of the traditional African religion and customs, educators about culture, counsellors, social workers and psychologists.

Denis (2006) looked at the rise of traditional African religion in post-apartheid South Africa. The study highlighted the impact of the missionaries on the African-indigenous beliefs. The establishment of the Traditional Health Practitioners Council of South Africa was expected to move traditional healing towards a positive direction. Despite the slow progress, Mbatha et al. (2012) inform us that some health units in some provinces in South Africa, such as the Free State, KwaZulu-Natal and North-West province, as well as the eThekwini and Ekurhuleni municipalities, have designated traditional medicine managers. These traditional medicine managers oversee traditional healing integration into the municipal health system, and encourage two-way referrals and collaboration between clinics and THPs.

With regard to regulating traditional healing, there are a number of professional associations, which are at the forefront of registering traditional healers. They include the Traditional Healers Organisation (THO), the African National Healers Association, the Bakgaga BaMaake Dingaka Association, the South African Sedibeng Dingaka Association, the Association of Traditional Healers of Southern Africa, the Congress of Traditional Healers of South Africa, the African Dingaka Association and the African Skilled Herbalists Association (Freeman \& Motsei 1992; Kale 1995).

The Traditional Healers Organisation is a non-statutory body established in 1970, which organises about 29000 traditional health practitioners in the country (THO 2012). The organisation offers training on how to treat different kinds of diseases through programmes, some of which are accredited by the Health and Welfare SETA (Sector Education and Training Authority). The African National Healers Association was founded in 1989 and is registered as a nonprofit organisation in South Africa under section 21 of Act No. 71 of 1997 (Government Gazette 1997). The details of the two associations have been obtained from their websites, whilst associations such as the African Skilled Herbalists Association, Bakgaga BaMaake Dingaka Association, the South African Sedibeng Dingaka Association, the Association of Traditional Healers of Southern Africa, the Congress of Traditional Healers of South Africa, the African Dingaka Association and the African Skilled Herbalists Association have no active websites.

In South Africa, the right to choose a healthcare system remains biased towards the Western practice in the sense that patients consulting traditional healers may find it difficult to deal with the employer after consultation. This is caused by the level of ambiguity and inconsistency when it comes to most private and government departments accepting sick notes for absenteeism issued by traditional 
healers (Mbatha et al. 2012:131). It should be mentioned again that traditional healers are not subsidised and they operate outside the formal healthcare setting at the financial cost of the patient alone (Mbatha et al. 2012:131). This is a disadvantage to both the patient and the healer because patients who have no money to go to the hospital may consult healers and promise to pay at a later stage, which sees the patient not benefitting from being helped by the government and the healer not being able to put food on the table.

\section{Research methodology}

This was a qualitative study in which hermeneutic phenomenology was employed as a research method. Despite it (phenomenology) being deep rooted in the Western epistemologies, it, however, proved to be a powerful way of understanding human lived experience from the participants' perspective and interpretation. The snowball sampling technique was employed to identify respondents who shared the same experiences and were most relevant to the study (Maluleka \& Ngoepe 2018:5). The choice of a snowball sampling was motivated by the fact that in South Africa, traditional healers are not properly documented and most of them are not known to many. The healers, however, know each other and they move in the same circles. Semi-structured interviews were used to collect data. The investigator interviewed 27 healers from the five regions of the province (Maluleka \& Ngoepe 2018:5). The reason why all regions were visited is because traditional healing is not a homogeneous healing system but varies from culture to culture, from region to region and from individual to individual (Mokgobi 2014:28). From the total number of healers interviewed, 19 were men and 8 were women (Maluleka \& Ngoepe 2018:5). This was a qualitative study, and issues of sampling and sample representativeness were not of great significance because the results were not generalised. On the contrary, the investigators focused on gathering deep data to address the objectives of the study. Interviews were conducted until data saturation was reached (Maluleka \& Ngoepe 2018:5).

\section{Ethical consideration}

The University of South Africa policy on research ethics (University of South Africa 2016) explains that all studies must be conducted ethically at all times and the rights and interests of all participants must be protected at all times.
Therefore, for this study, an ethical clearance was obtained from UNISA on 22 July 2016. Interview participants were informed as to who was conducting the research, why they were invited to participate, that participation is voluntary and they are free to withdraw from the study anytime, and that anonymity and confidentiality will be maintained at all times.

\section{Results and discussions}

This section presents and discusses the research findings based on the objectives of the study, namely:

- traditional healing in the Limpopo province postapartheid

- the relationship between Western medicine and traditional healing

- the regulation of traditional healing in the Limpopo province

- challenges faced by traditional healers in the Limpopo province

- possible solutions to challenges faced by traditional healers in the Limpopo province.

\section{Traditional healing in the Limpopo province post-apartheid}

In order to obtain an informed view on the matter, the investigator, through interviews, solicited views from healers on the status of indigenous healing in the Limpopo province. In cases where participants gave similar answers, only one answer was captured to avoid recording the same response multiple times. Participants were asked how they felt about their job as healers in the province. The following answers were given (see Table 1).

Denis (2006:313) predicted that traditional healing, as one of the elements contributing to indigenous knowledge systems in South Africa, will constitute an important field of scientific research. He further indicated that traditional African religions will occupy positions more important than ever before in public life.

Contrary to the predictions by Denis (2006:313), this study reveals that healers are still sidelined. They feel that they do not receive any support from the government and that they work on their own. Healers also feel that the government should create an environment that would enable them to

TABLE 1: How participants felt about their job as healers in the Limpopo province.

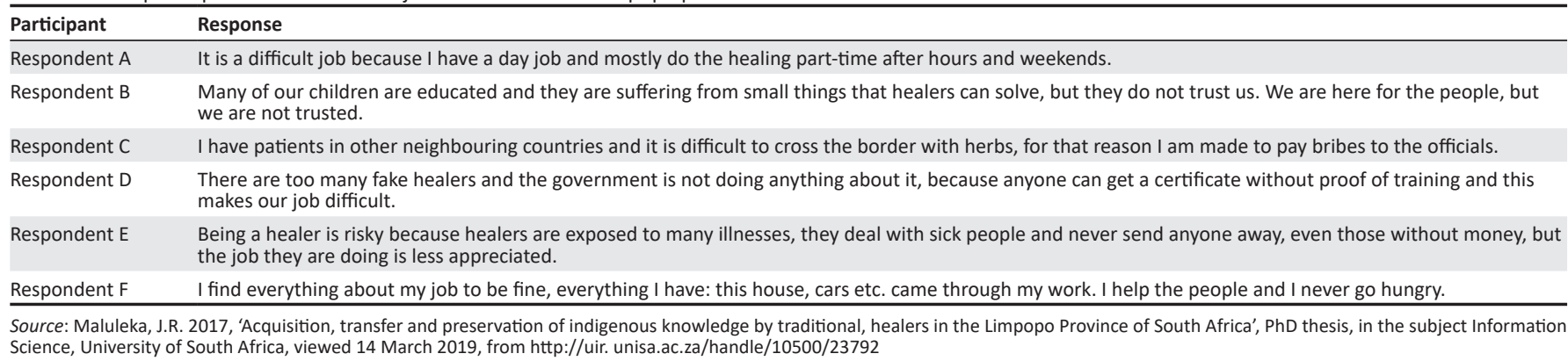


carry out their tasks, because they serve their communities and they play a role in the country's healthcare system, sometimes without being paid. They do not contribute to the state koffers because they work independently. The investigator further wanted to know whether the participants only subscribe to the ancestral beliefs or if there were other beliefs that they subscribed to as a result of how other religions perceived them. The following were the answers given (see Table 2).

Despite being taken for granted by other religious beliefs and being subjected to prejudice from other religions, traditional healers who have stood the test of time in Limpopo have no problem with other religious beliefs. It is also evident from the responses that some traditional healers are churchgoers. They view their job as similar to those of pastors who heal people using prayer. However, there are some churches that do not accommodate traditional healers and expect them to quit their practice before they can be members of their church.

Healers were also asked to explain how they marketed their services. This was aimed at finding out how South Africans got to know about different healers and the services they provided. The following were the answers given (see Table 3 ).

The findings suggested that healers hardly advertised their services because people in their areas were aware of what they were capable of. There was some consensus amongst respondents that new clients became aware of their services from the people they had helped before. They mostly worked on referrals and word of mouth. However, the participants believed that their ancestors played a major role in making sure that people came to them for healing. Some participants were of the view that their clothing did the marketing for them, as it displayed their status as healers in the communities, which set them apart from the rest of the people.

\section{The relationship between Western medicine and traditional healing}

The investigator further wanted to find out if there was some level of collaboration between the Western doctors and traditional healers. The following responses were received in this regard (see Table 4).

The findings suggested that traditional healers feel that Western medical practitioners undermined their work, whilst some spoke about the bad treatment they had received from the nurses when they took patients to clinics. Healers mentioned that patients who were referred to hospitals after consulting them first were given a tough time by nurses. These nurses made it clear that they should have consulted the hospital first. However, healers felt strongly that collaboration between Western medicine and traditional medicine was necessary because there were patients who might need help from either side of the camp. The participants indicated that patients who had to be put on a drip, who needed blood or human immunodeficiency virus (HIV) testing, amongst other illnesses, were referred to hospitals.

On the other hand, Western medical practitioners never refer patients to them even when they are sitting with illnesses that they do not understand or those that require traditional

TABLE 2: How traditional healers view other beliefs.

\begin{tabular}{|c|c|}
\hline Participant & Response \\
\hline Respondent A & I don't have problems with churches; they however tell people we are evil. \\
\hline Respondent B & $\begin{array}{l}\text { Ancestral beliefs and churches are not too different. As healers we sometimes train people who are prophets who happen to have powers to heal but using } \\
\text { prayer. }\end{array}$ \\
\hline Respondent C & According to me, healers and prophets are the same thing and as far as I know many healers also go to church. \\
\hline Respondent D & $\begin{array}{l}\text { There is nothing wrong with going to church as a healer, but it is not all churches that can accommodate healers. There are churches that refuse the use of } \\
\text { herbs to their members and, as a healer, I will never be part of that. }\end{array}$ \\
\hline Respondent E & You can go to church as a healer as long as you seek permission from the ancestors. \\
\hline Respondent G & $\begin{array}{l}\text { I don't have problems with other beliefs but the missionaries came into our country to destabilise us and interfere with our way of life so they are the ones } \\
\text { who have a problem with how we live. }\end{array}$ \\
\hline Respondent $\mathrm{H}$ & $\begin{array}{l}\text { My sister is one of the serious people I know when it comes to praying and issues of God. I do attend when I am around during those prayer sessions. I know } \\
\text { the Bible I know how to stand in front of people and praise the lord, but I know I am a healer. }\end{array}$ \\
\hline
\end{tabular}

Source: Maluleka, J.R. 2017, 'Acquisition, transfer and preservation of indigenous knowledge by traditional, healers in the Limpopo Province of South Africa', PhD thesis, in the subject Information Science, University of South Africa, viewed 14 March 2019, from http://uir. unisa.ac.za/handle/10500/23792

TABLE 3: How healers market their services.

\begin{tabular}{|c|c|}
\hline Participant & Response \\
\hline Respondent A & People in this area know me too well and what I am capable of. I don't need to go around showing people what I do. \\
\hline Respondent B & Mostly patients are referred to me by those I treated before. \\
\hline Respondent C & $\begin{array}{l}\text { Our clothing always tells people the type of people we are, we wear beads and cloths that set us apart from other people and everyone will just know we } \\
\text { healers and that's how people come to us for consultation. }\end{array}$ \\
\hline Respondent D & $\begin{array}{l}\text { The ancestors decide many things when it comes to our work. We get people from faraway places that never met us before but were sent to us by their } \\
\text { ancestors. }\end{array}$ \\
\hline Respondent E & My work does the marketing for me, I get people from places I have never been to before because of what they heard from people I helped. \\
\hline
\end{tabular}

Source: Maluleka, J.R. 2017, 'Acquisition, transfer and preservation of indigenous knowledge by traditional, healers in the Limpopo Province of South Africa', PhD thesis, in the subject Information Science, University of South Africa, viewed 14 March 2019, from http://uir. unisa.ac.za/handle/10500/23792 
TABLE 4: Collaboration between Western doctors and traditional healers.

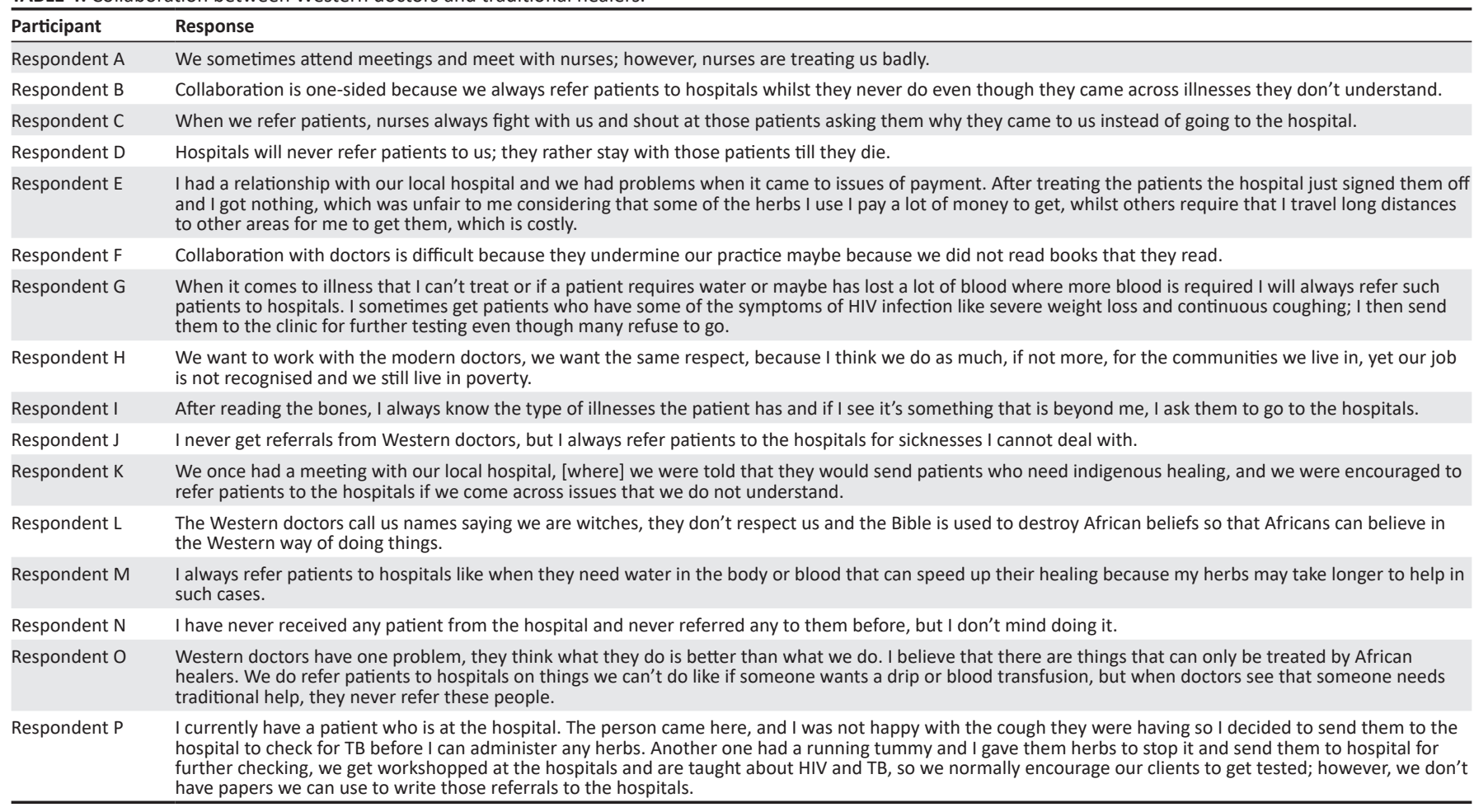

Source: Maluleka, J.R. 2017, 'Acquisition, transfer and preservation of indigenous knowledge by traditional, healers in the Limpopo Province of South Africa', PhD thesis, in the subject Information Science, University of South Africa, viewed 14 March 2019, from http://uir. unisa.ac.za/handle/10500/23792

healing. For example, the results of the study by Bopape, Mothiba and Malema (2013) suggest that illnesses such as hlogwana, ${ }^{1}$ themo/lekone, ${ }^{2}$ makgoma, ${ }^{3}$ sekgalaka ${ }^{4}$ and sephate ${ }^{5}$ are known to be cured by traditional healers in the Limpopo province. Nevertheless, hospitals never consider sending patients with such illnesses to healers and, as a result, healers have indicated that collaboration is one-sided because they are the ones referring patients whilst hospitals never do any referrals.

There was some consensus amongst participants that the well-being of patients was of great importance and that, similar to their Western counterparts, they had the best interest of their patients at heart; however, healers felt less respected by the Western doctors. They complained that some Western doctors called them witches and thought that what they did was better than what traditional healers did.

\section{The regulation of traditional healing in the Limpopo province}

According to Tshetlha (2015:279), the Interim Traditional Health Practitioners Council, which is responsible for regulating and controlling the traditional health practice,

1.That is 'anterior fontanelle' (see Maluleka \& Ngoepe 2018:4-9).

2.Retracted neck and red marks at the back of the neck (Maluleka \& Ngoepe 2018:4-9)

3.Some mysterious illnesses in the black communities associated with having sex with someone who did an abortion, someone whose partner died before proper cleansing was performed or attending the funeral of the mistress or lover who was with someone else (Maluleka \& Ngoepe 2018:4-9).

4.Eczema (Maluleka \& Ngoepe 2018:4-9).

5.An illness in children where such children scratch themselves in the nose and fingers whilst also pulling their fingers (Maluleka \& Ngoepe 2018:4-9). was inaugurated in February 2013. In May 2014, the sections of the THP Act that had given it full powers came into effect. The different purposes of the THP Act were to establish the Interim Traditional Health Practitioners Council of South Africa, provide for the registration, training and practices of traditional health practitioners in the Republic of South Africa and serve and protect the interests of members of the public who use the services of traditional health practitioners. This Act applies to the traditional health practice in the Republic of South Africa as well as the traditional health practitioners and students engaged in or learning traditional health practices in the Republic of South Africa (Government Gazette 2008).

The situation on the ground is somehow different. Associations with no statutory status are the ones registering the healers. Figure 1 displays some of the certificates the investigator has come across. All photographs were captured by the investigator.

During interviews, participants were asked if they belonged to any association and if it played any role in their practice. Table 5 presents participants' responses in this regard.

As shown with the certificates (Figure 1a-e) held by different healers, registration of traditional healers is mostly done by associations, which are not recognised by law. These associations have their downside. Some healers complained that sometimes the registration was done without proper verification of whether the healer had received training or not. This was confirmed by a close analysis of the certificate 

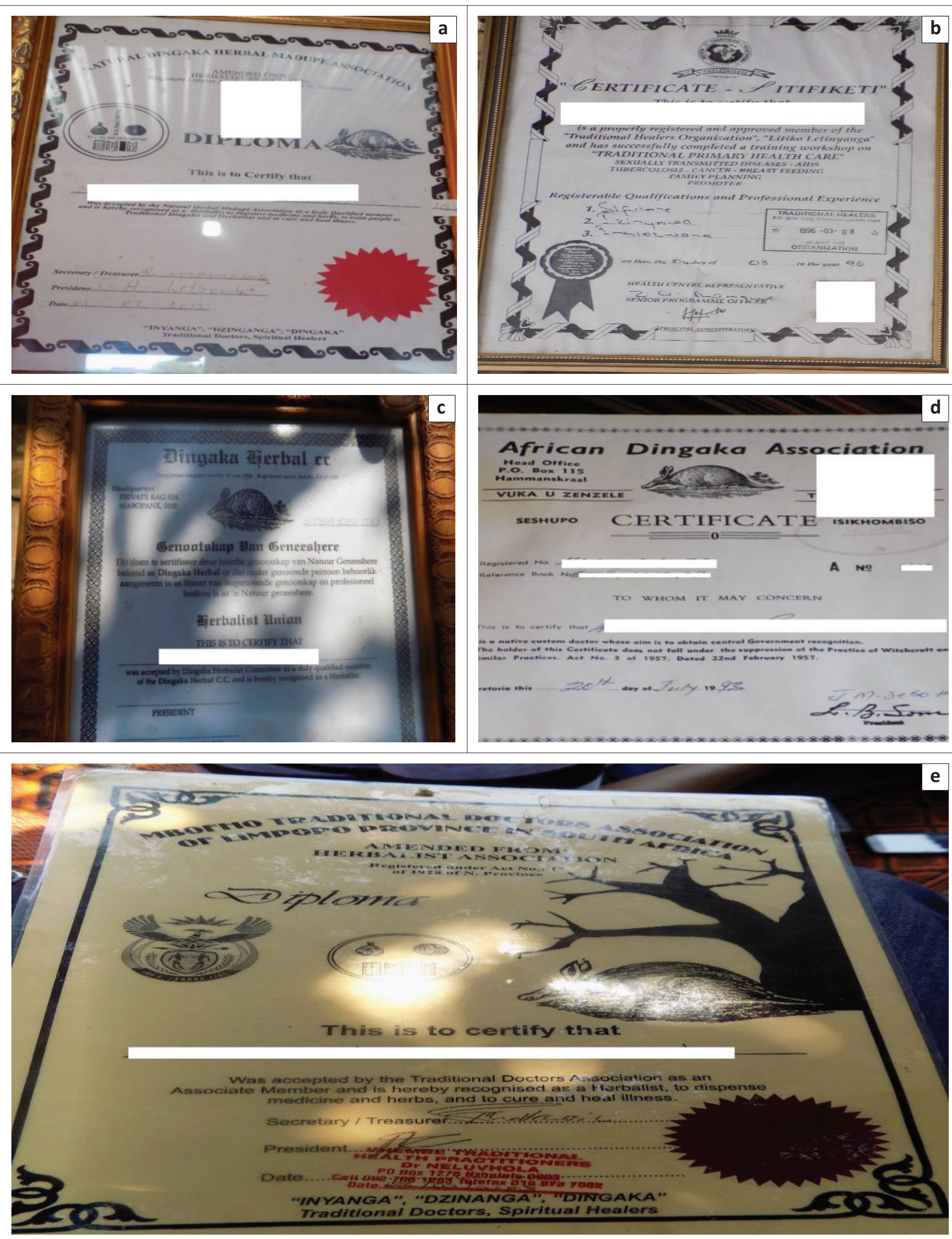

Source: Photos taken by authors

FIGURE 1: Certificates from (a) Natural Dingaka Herbal Madupe Association, (b) Traditional Healers Association, (c) Dingaka Herbal cc, (d) African Dingaka Association and (e) Mbofho Traditional Doctors Association of Limpopo province in South Africa. 
TABLE 5: Membership of associations and the role associations play in the practice of healers.

\begin{tabular}{|c|c|}
\hline Participant & Response \\
\hline Respondent A & I belong to the traditional health organisation. \\
\hline Respondent B & We belong to an association and have leaders, but our leaders don't communicate anything with us. \\
\hline Respondent C & I belong to an association and was given a certificate after undergoing training for a week on illnesses I already knew and treated before. \\
\hline Respondent D & I am a member of an association and on my certificate, it shows that I can treat only three illnesses, yet I am dealing with all sorts of illnesses on a daily basis. \\
\hline Respondent $\mathrm{E}$ & I belong to an association and I just attended their training so that I can get my certificate and continue with my work as a healer. \\
\hline Respondent F & I belong to an association and there is an office of traditional healers that is supposed to lead us, but I have never been there. \\
\hline Respondent $\mathrm{H}$ & $\begin{array}{l}\text { I am a member of an association, the problem is they prescribed very high prices for us to charge our clients which is not working because we deal with poor } \\
\text { communities and end up ignoring them. }\end{array}$ \\
\hline Respondent I & $\begin{array}{l}\text { I am affiliated to a professional association, but their offices are very far from our villages. We need offices next to where we stay because the office in } \\
\text { Johannesburg is not helping us. }\end{array}$ \\
\hline Respondent J & $\begin{array}{l}\text { I belong to the traditional health organisation, African Dingaka Association and was also registered by the provincial government as a healer. The associations } \\
\text { help when there is a dispute mostly with the trainees, but they also say they can help when patients are not paying after being treated, but I have never used } \\
\text { such a service before. }\end{array}$ \\
\hline Respondent K & I belong to the traditional healer's association and also have a certificate for the HIV and AIDS home-based care training I attended. \\
\hline Respondent M & I belong to a professional association, but I don't see how they are helping, even though I pay my fee every year. \\
\hline Respondent N & $\begin{array}{l}\text { I belong to a professional association, but as a healer I am guided by my ancestors. What I do and how I conduct myself as a healer is being monitored by my } \\
\text { ancestors, what associations need is money and as a healer it is my job to help the needy. }\end{array}$ \\
\hline Respondent O & $\begin{array}{l}\text { I am not yet registered with any association, but my mentor mentioned to me that I need to register with an association because we need protection as } \\
\text { healers when we face difficulties with clients, like in cases where clients are not paying or maybe clients are giving us hard times or when we come across } \\
\text { police carrying some herbs as they will need some form of identification. }\end{array}$ \\
\hline Respondent P & Yes. I belong to an association of spiritual healers and have certificates from our association. \\
\hline Respondent Q & $\begin{array}{l}\text { I was not trained as a healer; I just have knowledge of herbs, as a result I do not have a certificate. I usually get many herbs locally and buy those herbs that } \\
\text { can be found in other areas, because I do not have the documentation to travel with herbs. }\end{array}$ \\
\hline
\end{tabular}

Source: Maluleka, J.R. 2017, 'Acquisition, transfer and preservation of indigenous knowledge by traditional, healers in the Limpopo Province of South Africa', PhD thesis, in the subject Information Science, University of South Africa, viewed 14 March 2019, from http://uir. unisa.ac.za/handle/10500/23792

TABLE 6: Challenges faced by traditional healers during their healing practice.

\begin{tabular}{|c|c|}
\hline Participant & Response \\
\hline Respondent A & We normally get clients at night and at times I don't open because it might be robbers. \\
\hline Respondent B & There is no support from the government's side; we work on our own. \\
\hline Respondent C & We normally get clients who are seriously sick, and we help and end up not getting our money and there is no one to help us recover our money. \\
\hline Respondent D & $\begin{array}{l}\text { We always heal people and expect payment when they are healed, so once our job is done patients are healed, we mostly don't get paid or the payment is } \\
\text { mostly incomplete, and we depend on that money to buy herbs and to feed our families. }\end{array}$ \\
\hline Respondent E & Everything is very fine, there are no problems. \\
\hline Respondent F & There are no challenges thus far. \\
\hline Respondent G & $\begin{array}{l}\text { There are no challenges at all, I help the sick and ever since I left my job as a prison warder almost } 40 \text { years ago, I have never gone hungry, I do the job my } \\
\text { ancestors set me out to do and from my job I educated all my children. }\end{array}$ \\
\hline
\end{tabular}

Source: Maluleka, J.R. 2017, 'Acquisition, transfer and preservation of indigenous knowledge by traditional, healers in the Limpopo Province of South Africa', PhD thesis, in the subject Information Science, University of South Africa, viewed 14 March 2019, from http://uir. unisa.ac.za/handle/10500/23792

presented in this article. The certificates only contained signatures of the association leaders and no evidence of where the certificate holder received his or her training. Respondents mentioned that all that was needed for them to receive their certificates was to deposit money into the relevant bank account.

The investigator is of the view that this kind of practice has the potential to open doors for bogus healers who may easily apply for and obtain these certificates. There are always negative reports in the media about traditional healers and it is impossible to tell whether bogus healers are behind this, because it is impossible to differentiate at face value between a bogus healer and a legitimate healer who has received proper training. It is not possible to give the correct number of traditional healers currently practising because healers are scattered and registered by a number of non-statutory associations. Their numbers are not consolidated anywhere because these associations operate independently. There are also a huge number of healers who are not registered with any association but are dealing with patients on a daily basis.
The THPC is mandated to consolidate the numbers and develop a database of traditional healers, but that is proving to be difficult because of the current state of traditional healing in the country.

\section{Challenges faced by traditional healers in the Limpopo province}

Participants were asked to discuss challenges they face during their traditional healing practice and the following responses were obtained (see Table 6).

Traditional healers have a safety challenge, especially female healers who mentioned that sometimes they do not open their gates at night for clients because they fear robbers. At times, criminals consult them for muti [herbs] to use for criminal activities and they find themselves in a difficult position. Furthermore, it is difficult to work long hours at night, especially if they have a day job and are expected to report for duty the next morning (Maluleka \& Ngoepe 2018:7). 
TABLE 7: How the situation in the Limpopo province could be improved.

\begin{tabular}{|c|c|}
\hline Participant & Response \\
\hline Respondent A & We can be really happy if we can get the same treatment as Western doctors. \\
\hline Respondent B & Western doctors don't take us seriously and we can be happy if they can show some respect towards us. \\
\hline Respondent C & Government must give us a chance, work with us because we are doing all we do for our communities. \\
\hline Respondent D & $\begin{array}{l}\text { When people come to see us during working days, they get punished at work because we can't give sick notes as we don't have stamps and documents to use. } \\
\text { The government should provide us with such resources. }\end{array}$ \\
\hline Respondent E & Before anyone is granted the certificate to practice, the trainer must be present to sign the certificate to authenticate the certificate. \\
\hline Respondent F & $\begin{array}{l}\text { Missionaries came with an aim to destroy our own way of living and doing things, our healing powers come from our ancestors; our government should do } \\
\text { more in educating our people how Africans do their things and how they survived all these years. }\end{array}$ \\
\hline Respondent G & $\begin{array}{l}\text { To get access to where important herbs are, we need to pay, and this makes it difficult for us. Most of our clients are poor and we normally don't collect money } \\
\text { upfront. We deal with their problems and when they are completely healed, they pay us. Such payments are mostly made in terms, many don't have cash to } \\
\text { pay and if we ask too much money for getting herbs, our services will be expensive and everyone will suffer. We work for the nation and the government } \\
\text { should help us get access to these herbs. }\end{array}$ \\
\hline Respondent H & $\begin{array}{l}\text { Herbalists, mostly Indians who sell herbs, influence the increase in fake healers because anyone who is not a healer go to them, buy herbs and claim to be } \\
\text { healers and rob people. If you are a true healer, you must go get your own herbs in the wild because you were taught. }\end{array}$ \\
\hline Respondent I & Those who sell herbs must prove that they are trained healers, so that the correct herbs are sold to healers. \\
\hline
\end{tabular}

Source: Maluleka, J.R. 2017, 'Acquisition, transfer and preservation of indigenous knowledge by traditional, healers in the Limpopo Province of South Africa', PhD thesis, in the subject Information Science, University of South Africa, viewed 14 March 2019, from http://uir. unisa.ac.za/handle/10500/23792

Healers are less supported by the government despite their playing a major role in the health of the people in the country. They are exposed to different health hazards because they deal with different illnesses at times and sometimes without being paid. Because of little protection from the government, healers are exploited by some government officials who demand bribes when they find them in possession of herbs or when they try to cross the border to collect herbs or to check on their clients (Maluleka \& Ngoepe 2018:7).

Traditional healers depend on the money they make from healing people to put food on the table. They mostly heal people and never receive payment. They end up finding themselves in a difficult situation because their ancestors do not allow them to turn the sick people away if they come to them without money. Consequently, they treat the people, but their families go hungry and they end up with no money to buy herbs (Maluleka \& Ngoepe 2018:7).

There is a serious concern amongst healers about the bogus healers practising in the province. Many of these bogus healers are not even South Africans and they find it very easy to practise as healers in the country. The interviews have revealed that it is easy to obtain a certificate from the non-statutory bodies offering certificates to healers, which makes it easy for these bogus healers to operate. This makes the job of genuine healers very difficult as they are painted with the same brush when something bad that was done by a bogus healer is reported (Maluleka \& Ngoepe 2018:7).

\section{Possible solutions to challenges faced by traditional healers in the Limpopo province}

When the interview participants were asked how the current situation in the province could be improved with regard to traditional healing in the province, the investigator received the following responses (see Table 7).

Summerton (2006:17) argues that the Western health practitioners' critical view of traditional medicine is based on notions that perceive traditional health practitioners as posing a danger to the health of their patients. This mindset has to change; interviews revealed that traditional healers demand respect from their Western counterparts as well as the government. According to Summerton (2006:17), Western practitioners lack the knowledge about traditional theories of disease and health. This causes tension and stands in the way of collaboration.

The Department of Health is also not doing enough to integrate traditional healing into the health system despite reports that the majority of the people in non-developed countries visit healers first before going to Western hospitals. The THPC must get its house in order and get to work so that law and order are maintained within the practice. It is very easy to get into the practice, and the sooner they start taking charge and putting control measures in place, the better it will be. The respondents feel that healers should be given permission to access different places where herbs can be found, and those who practise without the proper documentation and training should be prevented from selling herbs so as to prevent bogus healers from obtaining herbs.

Participants were further asked to make some recommendations on how the situation in the province could be improved, for which the following responses were received (see Table 8 ).

Healers recommend that strict measures should be put in place for those who sell herbs. The respondents are concerned that those who sell herbs are killing trees and negatively affecting their practices, because they collect large quantities at once and trees never have the chance to recover as they are left exposed at those times.

Healers also feel that there should be regional offices where such issues can be reported and addressed. Having one centralised office in the city will not help with the domestic problems they are facing. Furthermore, respondents are of the view that children should be taught about their culture from an early age so that they can 
TABLE 8: Recommendations on how the situation could be improved in the Limpopo province.

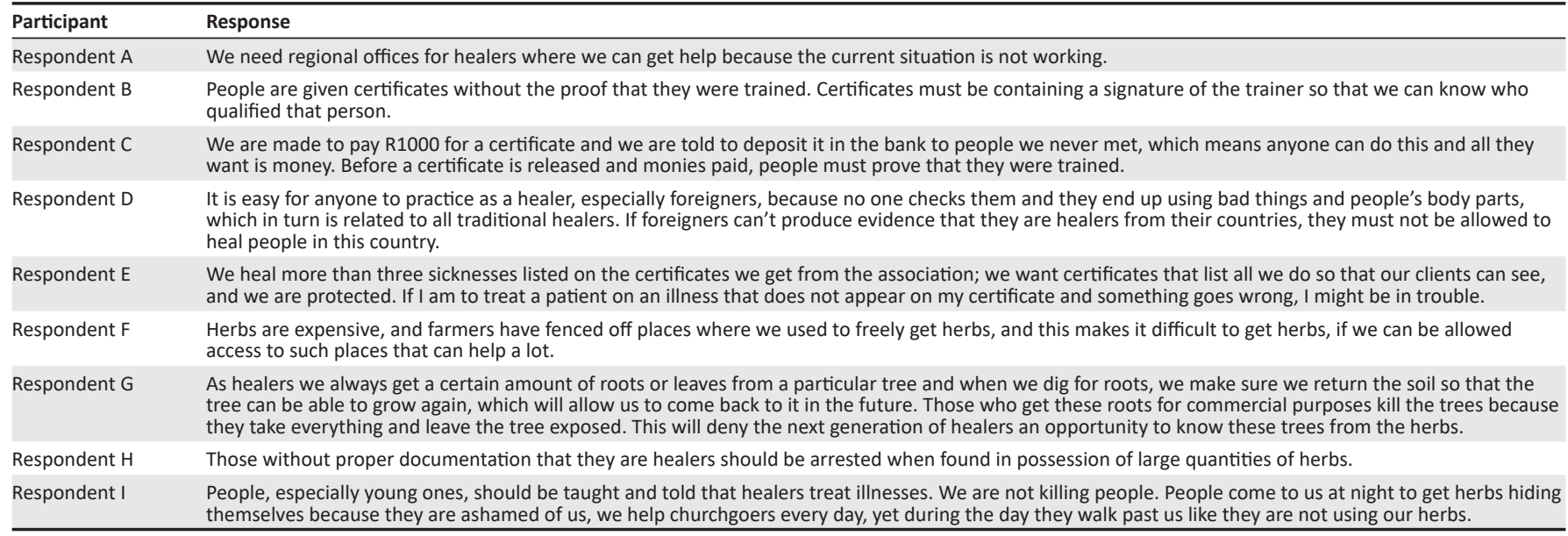

Source: Maluleka, J.R. 2017, 'Acquisition, transfer and preservation of indigenous knowledge by traditional, healers in the Limpopo Province of South Africa', PhD thesis, in the subject Information Science, University of South Africa, viewed 14 March 2019, from http://uir. unisa.ac.za/handle/10500/23792

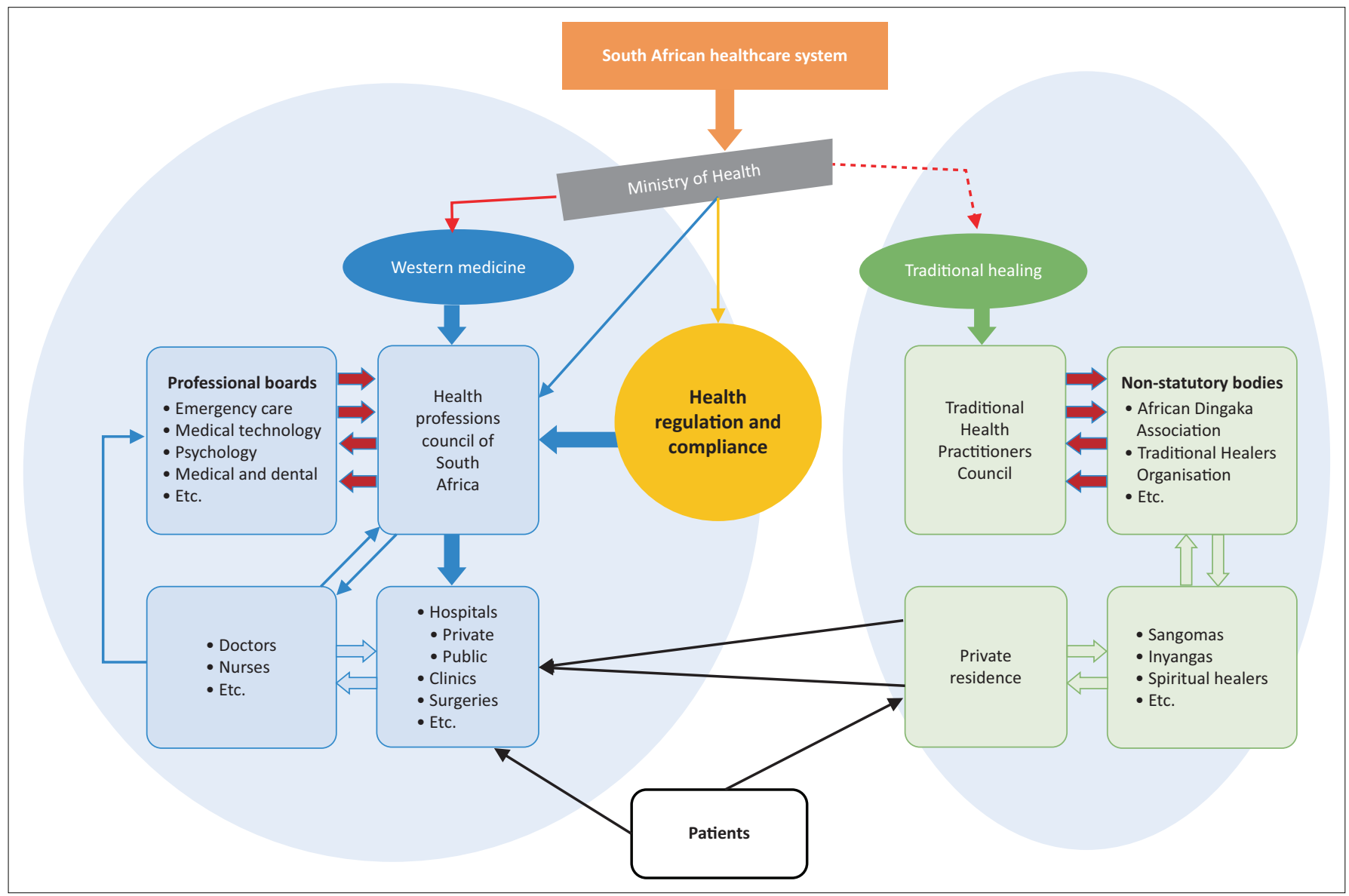

FIGURE 2: The status of traditional healing in South Africa.

grow up knowing who they are and where they come from. This will help sustain African cultures and allow them to make an informed choice when they reach adulthood.

\section{Conclusion and recommendation}

This study concludes that despite government passing laws to support traditional healing in South Africa, traditional healing remains marginalised and healers are working on their own outside the country's healthcare system. They do so under difficult conditions and at times without payment. The study results suggest that the work done by traditional healers is often undermined by the Western medicine practitioners. Furthermore, collaboration is mainly onesided where traditional healers refer some of their patients to hospitals when they find difficulty in helping them but Western doctors rarely refer patients to traditional healers if they come across illnesses that they do not understand and that may be remedied through traditional methods 
(see Figure 2). When it comes to regulating traditional healing in South Africa, the THP Act stipulates that no person should act as a traditional healer in the country without registration; however, healers continue to be registered and paying membership to non-statutory bodies, which is often done without verification, which allows bogus healers to operate easily in the country.

It is recommended that government should play an active role in ensuring that healers are formally incorporated into the country's healthcare system, which will benefit both the healers and the communities they serve. The contribution of traditional healing to the national healthcare system is downplayed and not maximised optimally. A country like South Africa will do well to maximise all the opportunities available to the benefit of its population. Healers are exposed to different kinds of illnesses with limited resources and, therefore, the government has to intervene to protect healers from such illnesses and ensure the sick are treated under good conditions (Maluleka \& Ngoepe 2018:8). The laws passed by government on traditional healing need to be implemented and enforced. Traditional healing is harbouring criminals who continue to do their criminal activities hiding behind traditional healing. This can be curbed by properly regulating traditional healing, which will eliminate the current exploitation it faces from those with dubious intentions. Community leaders should also play an active role in educating the youth about African practices and how important it is to preserve these practices. The damage done through political and religious interference could never be undone, but all is not lost.

\section{Acknowledgements}

This article is a reworked paper of research conducted for purposes of acquiring my PhD, Maluleka, J.R., 2017, 'Acquisition, transfer and preservation of indigenous knowledge by traditional healers in the Limpopo province of South Africa', in the subject Information Science at the University of South Africa, under Prof. M.S. Ngoepe (supervisor) and Prof. P. Ngulube (co-supervisor).

\section{Competing interests}

The author declares that he has no financial or personal relationships that may have inappropriately influenced him in writing this article.

\section{Author's contributions}

The author has declared that he is the sole author of this research article.

\section{Funding information}

The author received no financial support for the research, authorship and/or publication of this article.

\section{Data availability statement}

The data that support the findings of this study are available from the author upon reasonable request.

\section{Disclaimer}

The views and opinions expressed in this article are those of the author and do not necessarily reflect the official policy or position of any affiliated agency of the author.

\section{References}

Ashforth, A., 2005, Witchcraft, violence, and democracy in South Africa, University of Chicago Press, London.

Bopape, M.A., Mothiba, T.M. \& Malema, R.N., 2013, 'Indigenous practices of Traditional Health Practitioners' (THPs) methods by mothers of children admitted to the Polokwane/Mankweng Hospital complex, Limpopo Province, South Africa', African Journal for Physical Health Education, Recreation and Dance (Suppl. 1) African Journal for Physical Hear Education, Recreation and Dance (Suppl. 1), handle/10386/1274/bopape_indigenous_2013.pdf?sequence=1\&isAllowed=y.

Denis, P., 2006, 'The rise of traditional African religion in post-apartheid South Africa', Missionalia 34(2/3), 310-323, viewed 10 October 2015, from https://www. researchgate.net/profile/Philippe Denis4/publication/265042701 The rise of traditional African religion in post-apartheid South Africalinks/546ddd0̄60cf2a 7492 2 c56098f/The-rise-of-traditional-African-religion-inpost-apartheid-South-Africa.pdf

Freeman, M. \& Motsei, M., 1992, 'Planning health care in South Africa - Is there a role for traditional healers?', Social Science and Medicine (11), 1183-1190, viewed 16 November 2015, from https://www.sciencedirect.com/science/article/abs/ pii/027795369290311D.

Government Gazette, 1997, Non-Profit Organization Act, No 71 of 1997, Cape Town, viewed 24 April 2020, from http://www.saflii.org/za/legis/num_act/noa1997287. pdf.

Government Gazette, 2008, Traditional Health Practitioners Act, No. 22 of 2007 Pretoria, viewed 24 June 2015, from https://www.gov.za/documents/traditionalhealth-practitioners-act.

Kale, R., 1995, 'Traditional healers in South Africa: A parallel health care system' British Media Journal 310, 1182-1185, viewed 07 October 2015, from https:// www.ncbi.nlm.nih.gov/pmc/articles/PMC2549561/pdf/bmj00591-0038.pdf.

Limpopo Provincial Government, 2014, Limpopo, viewed 17 June 2016, from, http:// www.limpopo.gov.za/index.php?option=com_content\&view=article\&id=6\&ltemid $=11$.

Maher, P., 1999, 'A review of traditional aboriginal health beliefs', Australian Journal of Rural Health 7, 229-236, viewed 28 June 2016, from https://onlinelibrary.wiley. $\mathrm{com} / \mathrm{doi} / \mathrm{pdf} / 10.1111 / \mathrm{j} .1440-1584.1999 . \mathrm{tb00462} \cdot \mathrm{x}$ ? casa token= 4bxe8z74q1IAAAAA:KsarEAy5d5-zZ5NBxJReyQBoacYuB5EeJDqImHyX̄ XrbQHU bzSu7rwqn8nWLsmJo49r2 ARcbwKUaAMpl.

Maluleka, J.R. 2017, 'Acquisition, transfer and preservation of indigenous knowledge by traditional, healers in the Limpopo Province of South Africa', PhD thesis, in the subject Information Science, University of South Africa, viewed 14 March 2019, from http://uir. unisa.ac.za/handle/10500/23792.

Maluleka, J.R. \& Ngope, M., 2018, 'Integrating traditional medical knowledge into mainstream healthcare in Limpopo Province', Information Development 35(5), 714-723. https://doi.org/10.1177/0266666918785940

Mathibela, M.K., Egan, B.A., Du Plessis, H.J. \& Potgieter, M.J., 2015, 'Socio-cultura profile of Bapedi traditional healers as indigenous knowledge custodians and conservation partners in the Blouberg area, Limpopo Province, South Africa' Journal of Ethnobiology and Ethnomedicine 11(1), 49, viewed 22 April 2016, from https://link.springer.com/article/10.1186/s13002-015-0025-3.

Mbatha, N, Street, A.R., Ngcobo, M. \& Gqaleni, N., 2012, 'Sick certificates issued by South African Traditional Health Practitioners: Current legislation, challenges and the way forward', South African Medical Journal 102(3), 129-131, viewed 13 June 2016, from http://www.samj.org.za/index.php/samj/article/view/5295/3909.

Mokgobi, M.G., 2014, 'Understanding traditional African healing', African Journal for Physical Health Education, Recreation and Dance (AJPHERD) (Suppl. 2) 24-34, viewed 3 March 2019 from https://www.ncbi.nlm.nih.gov/pmc/ articles/PMC4651463/.

Richter, M., 2003, Traditional medicines and traditional healers in South Africa: A discussion paper prepared for the Treatment Action Campaign and AIDS Law Project, viewed 22 February 2017, from http://www.hst.org.za/uploads/files/ TAC_Law_Proj.pdf.

Sodi, T., Mudhovozi, P., Mashamba, T., Radzilani-Makatu, M., Takalani, J. \& Mabunda J., 2011, 'Indigenous healing practices in Limpopo Province of South Africa: A ., 2011, 'Indigenous healing pral Kournal of Health Promotion and Education qualitative study', International Journal of Health Promotion and Education 49(3), 101-110, viewed 12 November 2015, from https://www.tandfonline. $\mathrm{com} / \mathrm{doi} / \mathrm{abs} / 10.1080 / 14635240.2011 .10708216$ ?casa_token=CjGRqu8YencAA AAA:hqt7FO47z_7Ts-50qb848NQWiSgMv6eeZByy1UT70HIdYyrO0Tdldy6DKXJ5 vf1Zu6P4uG46_0eC.

Summerton, J.V., 2006, 'Western health practitioners' view about African traditional health practitioner's treatment and care of people living with HIV/AIDS' Curationis 29(3), 15-23, viewed 17 October 2015, from https://curationis.org.za/index.php/ curationis/article/view/1089. 
Traditional Healers Organisation (THO), 2012, Traditional healers say no to integration viewed 13 June 2016, from http://tho-news.blogspot.com/2012/11/traditionalhealers-say-no-to.html.

Tshetlha, B., 2015, 'Traditional health practitioners and the authority to issue medica certificates', South African Medical Journal 105(4), 279-280, viewed 10 June 2016, from https://www.ajol.info/index.php/samj/article/view/120377.
Union Gazette Extraordinary, 1957, Witchcraft suppression act, No 3 of 1957, Union of South Africa, viewed 24 April 2020, from https://www.gov.za/sites/default/files/ gcis_document/201505/act-3-1957.pdf.

University of South Africa, 2016, Policy on research ethics, viewed 24 April 2020, from https://www/unisa services/research\%20support/Policy\%20on\%20Research\%20Ethics.pdf. 